\title{
Brand Extension in the FMCG Segment - An Empirical Study on Perception of Brand Extension by Consumers of Kolkata
}

\author{
Indrani Saha, M.Com, FCA \\ Associate Professor, Department of Commerce, Shri Shikshayatan College, Kolkata, India.
}

\begin{abstract}
The cost of introducing an entirely new brand is often very high, accompanied by risk of failure of new brands in an overcrowded market. These factors encourage firms to resort to brand extensions especially in the FMCG segment, to exploit the existing brand equity of the parent brand. The present research study examines in depth, the perception and behaviour of the consumers of Kolkata towards brand extensions in the FMCG segment. The study also strives to determine the factors that influence the consumers to accept brand extensions in the FMCG segment. The hypotheses developed for this empirical study were tested statistically with the help of SPSS version 16. The factors like perceived similarity and fit between parent brand and its extended brand, reputation of the parent brand and its impact on extended brand, the nature of consumers of Kolkata - whether they avoid perceived risk involved in the new brands or not, have been critically examined in the research study. The study is based on primary survey, covering all 141 wards under Kolkata Municipal Corporation, to get overall views, perception and acceptability of brand extensions in FMCG segment.
\end{abstract}

Key Words: Brand Extension, Brand Loyalty, Brand Equity, Extended Brand, FMCG (Fast Moving Consumer Goods), Kolkata Consumers, Parent Brand, Perceived Risk.

\section{Introduction}

Brand extension strategy is a very widely used mechanism in brand management. This strategy is extensively used in the FMCG (Fast Moving Consumer Goods) segment. The history of brand extension can be traced back to the 1960s. Gamble, 1967 [1] in his study mentioned the application of brand extension strategy as early as 1960s. The concept of brand extension started to get popular in the 1980s. Brand concept is defined as the image that a consumer thinks of when exposed to a particular core brand, Chung, Anna, \& Margo, 2001 [2]. Brand Extension involves utilizing and applying the established core brand name to new products to obtain the equity of the original core brand and also to capture new and unexplored market segments.

Dr. Edward Tauber, 1988 [3], who originated the term brand extension, opined on brand extension as, "A key to successfully stretching a brand is to view brand extension as a strategic tool, not just as a new product." Considering the difficulty to launch a new brand with increasing cost and increasing competition, the popularity of brand extensions is understandable. Some of the uses and functions of brand extensions are:

(i) Providing a new product with a competitive advantage.

(ii) Allowing greater efficiency through brand-wide advertising and promotions making it cost effective.

(iii) Increasing consumer awareness for newly introduced brands.

(iv) Familiarity with the core brand and, therefore, offers a less risky route to a new product category and appeal in the marketplace.

(v) Helping to define a recently formed brand in the minds of consumers, which in future helps the extensions.

(vi) Enabling to redefine and revitalize declining brands.

(vii) Disassociating a brand from a product at the end of its lifecycle.

The discipline of brand extension is discussed by many authors, such as Aaker, 1991 [4]; Kapferer, 2004 [5]; Kim \& Lavack, 1996 [6]; Nijssen, 1999 [7]; De Chernatony, 2003 [8]; Grime \& Smith, 2002 [9]; Kotler \& Armstrong, 2006 [10], who in their studies analyse brand extension process with brand extension strategy. When companies decide to move into new product categories they are faced with the choice of introducing a new brand or extending an existing brand. The advantage of pursuing a brand extension strategy is that it is less costly, given the fact that the existing brand enjoys some level of brand awareness. It is likely that a customer will prefer to try a new product from a known brand name than a new brand as has been revealed by a study done by Swaminathan et.al, 2001 [11].

\subsection{Indian FMCG Sector and Brand Extension Strategy}

With a population of more than one billion, India is one of the largest economies in the world in terms of purchasing power and increasing consumer spending, only next to China. The FMCG sector is the fourth largest sector in India, with an estimated market size of around Rs. 2000 billion. In the last five years, average growth in the FMCG sector accelerated at a compound rate of 17.3\% per annum as per the IBEF Report, 2013 
[12]. The FMCG sector in India is characterised by strong presence of global players, competition between organised and unorganised sectors, good distribution network and low operational costs. The country enjoys relatively cheaper labour cost with adequate supply of raw materials. Food products and personal care together give two-thirds of the sector's revenue. Around 1.9\% of the nation's total FDI inflows during April 2000 to September 2012 were in this sector. With changing lifestyle and increasing consumer demand, the Indian FMCG market is expected to cross US $\$ 80$ bn by 2026 . The Indian FMCG sector is highly fragmented with many unorganised players and is volume driven with low profit margins. The growing popularity of organised retail is expected to propel the growth of the FMCG sector in future. Moreover, there is an untapped market potential in the rural areas. According to IBEF Report 2013, [12] the segment-wise breakup of the market share of the FMCG sector in India is as follows : Food \& Beverage 53\%, Personal Care 20\%, Tobacco 15\%, Household Care $10 \%$ and Lighting $2 \%$.

A huge demand for existing products is encouraging more FMCG players to extend their existing brand and expand their product portfolio as well. To increase their market share and sustain long term growth, avoid the risk of new brand launch failure and achieve cost efficiency, most of the FMCG companies are going for brand extension strategy. The existing reputation of the parent brand helps extensions gaining market share faster than new launches.

In the FMCG segment we have seen "Dove" Soap (the parent Brand) extend to Dove Shampoo, Dove Conditioner, Dove Hair Oil, and Dove Moisturiser; "Dettol" antiseptic (the parent Brand) extend to Dettol Soap, Dettol Dish Washing Gel; "Pond's" Cream (parent Brand) extended to Pond's Age Miracle Cream; "Amul" Milk (the parent Brand) extend to Butter, Ice Cream, Chocolate, Dairy Whiteners, Curd, Cheese, Pizza etc.

In the Nielsen's Survey Report, 2012, [13] it has been pointed out that Brand stretches are preferred by the brand managers six times more than launching a new brand. The study carried out by Nielsen has also revealed that marketing practitioners prefer extending their existing brands rather than launching a completely new brand. The three important benefits being Leverage Equity, Spend Efficiency and Faster Adoption by the customers (Source: Nielsen Report). The Nielsen audit data also revealed that contribution of brand stretching is significant and fast growing, contributing as much as 30\% in 2011. The contribution to growth is $38 \%$ for the respective brands. Moreover, market analysis of Indian FMCG brands showed that success of extending existing parent brand is five times higher. The existence of brand extension strategy was there three decades ago, and it is multiplying more in the current economic scenario. Since brand extension in FMCG segment is more prevalent, the research has been carried out to assess the outcome of such strategy in the FMCG segment specifically with reference to Kolkata.

Table 1 lists the major players operating in the FMCG segment in India during the year 2012-13. The Companies appearing on this list are taken from the list of the top 500 companies as per the annual survey done by The Economic Times of India [14].

Table 1: Major Players in FMCG Industry in India

\begin{tabular}{|l|c|c|}
\multicolumn{1}{c}{ Company Name } & $\underline{2}$ Year: 2012-13 (Rs. million) \\
\cline { 2 - 3 } \multicolumn{1}{c|}{} & $\underline{\text { Pevenue }}$ & $\underline{\text { Profit After Tax }}$ \\
\hline ITC Limited & $325,051.4$ & $7,6080.7$ \\
\hline Hindustan Unilever Limited & $281,870.3$ & $38,289.8$ \\
\hline $\begin{array}{l}\text { Gujarat Co-operative Milk Marketing Federation Limited } \\
\text { (GCMMF) }\end{array}$ & $137,351.5$ & N.A. \\
\hline Nestle India Limited & $83,655.6$ & $10,679.3$ \\
\hline Godrej Consumer Products Limited & $66,041.2$ & $7,961.0$ \\
\hline Dabur India Limited & $62,707.0$ & $7,634.2$ \\
\hline Britannia Industries Limited & $62,376.5$ & $2,595.0$ \\
\hline GlaxoSmithKline Consumer Health Care Limited & $33,012.8$ & $4,367.6$ \\
\hline Emami Limited & $17,547.8$ & $3,247.4$ \\
\hline Procter \& Gamble Hygiene \& Health Care Limited & $17,537.4$ & $2,032.2$ \\
\hline
\end{tabular}

(Source: The Economic Times of India Top 500 Companies in India \& Company Annual Reports, 2013).

\subsection{Literature Review}

Substantial amount of literature has been developed over the past three decades. Over 70 Scholarly Articles, Reference Books and Research Reports were referred to in this study. The review of literature, some of which have been summarised in Table 2, covered the following areas:

a) Defining Brand and Its Importance.

b) Brand Extension: Types, Benefits, Risks, Relationship with Brand Equity. 
c) Brand Loyalty and Consumer's Perception of Brand Extension.

d) Study of Brand Extension in FMCG Segment.

Table 2 : Summary of Important Literature

\begin{tabular}{|c|c|}
\hline Author(s) / Journal /Source & Major Observations \\
\hline $\begin{array}{l}\text { Tauber E.M. (1981) "Brand Franchise Extension: New } \\
\text { Product Benefits From Existing Brand Names"; Business } \\
\text { Horizon, vol.24. [15] }\end{array}$ & $\begin{array}{l}\text { To be successful in brand stretching, brand } \\
\text { extension should be considered as a strategic } \\
\text { tool. }\end{array}$ \\
\hline $\begin{array}{l}\text { Aaker, David and Keller, K.L (1990) "Consumer Evaluation } \\
\text { of Brand Extensions"; Journal of Marketing, vol.54 } \\
\text { (January). [16] }\end{array}$ & $\begin{array}{l}\text { Success of Brand Extensions often depends upon } \\
\text { certain assumptions about consumer behaviour. }\end{array}$ \\
\hline $\begin{array}{l}\text { Park, C.W. ; Milberg, S. and Lawson, R. (1991) "Evaluation } \\
\text { of Brand Extensions, The Role of Product Similarity and } \\
\text { Brand Concept Consistency"; Journal of Consumer } \\
\text { Research, (September) [17] }\end{array}$ & $\begin{array}{l}\text { Perceived similarity in the consumers mind helps } \\
\text { in category extension. }\end{array}$ \\
\hline $\begin{array}{l}\text { Boush, D.M. and Loken, B. (1991), "A Process-Tracing } \\
\text { Study of Brand Extension Evaluation"; Journal of Marketing } \\
\text { Research, vol.28. [18] }\end{array}$ & $\begin{array}{l}\text { Brand Extension is the better way to achieve } \\
\text { growth in the cost controlled world. }\end{array}$ \\
\hline $\begin{array}{l}\text { Thamaraiselvan, N. and Raja, J. (2008), "How do } \\
\text { Consumers Evaluate Brand Extensions - Research Findings } \\
\text { from India"; Journal of Services Research, vol.8 ,Issue } 1 . \\
\text { [19] }\end{array}$ & $\begin{array}{l}\text { How do consumers evaluate brand extensions in } \\
\text { the Indian market - an empirical study. }\end{array}$ \\
\hline $\begin{array}{l}\text { Loken, B. and John, R.D. (1993), "Diluting Brand Beliefs: } \\
\text { Where Do Brand Extensions Have a Negative Impact?" } \\
\text { Journal of Marketing, vol.57 (July).[20] }\end{array}$ & $\begin{array}{l}\text { Failure of Brand Extensions will have negative } \\
\text { effect on core brand and may result in dilution of } \\
\text { parent brand's image. }\end{array}$ \\
\hline $\begin{array}{l}\text { Franziska Volckner and Henrik Sattler (2006), "Drivers of } \\
\text { Brand Extension Success", Journal of Marketing, vol.70 } \\
\text { (April). [21] }\end{array}$ & $\begin{array}{l}\text { The empirical analysis considered the direct } \\
\text { relationship between success factors and } \\
\text { extension success. }\end{array}$ \\
\hline $\begin{array}{l}\text { Apostolopoulou, A. (2002), "Brand Extensions by U.S. } \\
\text { Professional Sport Teams; Motivations and Keys to } \\
\text { Success", Sports Marketing Quarterly, vol.11, No. 4. [22] }\end{array}$ & $\begin{array}{l}\text { The paper established six key factors for } \\
\text { successful extension of brand. }\end{array}$ \\
\hline $\begin{array}{l}\text { Pitta, A. and Katsanis, P.L. (1995), "Understanding Brand } \\
\text { Equity for Successful Brand Extension", Journal of } \\
\text { Consumer Marketing vol.12. [23] }\end{array}$ & $\begin{array}{l}\text { The paper brings out the difference between line } \\
\text { and category extensions. }\end{array}$ \\
\hline $\begin{array}{l}\text { Chen, C.H. Chen, (2000), "Brand Dilution Effect of } \\
\text { Extension Failure - A Taiwan Study", Journal of Product and } \\
\text { Brand Management, vol. 9(4). [24] }\end{array}$ & $\begin{array}{l}\text { The study conducted in Taiwan, established that } \\
\text { the extended brand is perceived as cannibalizing } \\
\text { the parent brand by eating into the total sales of } \\
\text { the parent brand. }\end{array}$ \\
\hline $\begin{array}{l}\text { Ries, A.L. and Trout, T. (1986), Positioning "The Battle For } \\
\text { Your Mind" (1st Ed), New York, McGraw Hill. [25] }\end{array}$ & $\begin{array}{l}\text { The book stated that even if the brand is used } \\
\text { congruously, the success to extend a brand would } \\
\text { be at the expense of the parent brand. }\end{array}$ \\
\hline
\end{tabular}

\subsection{Research Gap}

(i) The FMCG segment in India being one of the largest emerging markets with a billion plus population is also one of the largest economies of the world in terms of purchasing power with a middle class population of over 500 million.

(ii) Globally, the middle class will expand dramatically by 2020. It is expected that over 1 billion new customers will be driving consumption patterns across the world.

(iii) The FMCG sector has a strong growth momentum in India and globally. To cater to the growing market demand for new products, FMCG companies are leveraging on their parent brand names to launch new products or variants.

(iv) The Literature Survey shows that very few studies have been done on the FMCG sector and how consumers perceive Brand Extensions in this sector.

(v) No comprehensive study has been done on the outcome of Brand Extension in the FMCG sector in the Indian market, particularly in Kolkata.

\subsection{Objectives of the Study}

In view of the above discussions, the following are the objectives that have been focused in the study.

(i) The research study primarily examines in-depth the perceptions and purchase behaviour pattern of Kolkata consumers with respect to products launched through brand extensions in the FMCG segment and to find out how Kolkata's consumers' perceive brand extension of FMCG segment.

(ii) To identify whether demographic factors have any influence on Kolkata consumers' evaluation of brand extension in the FMCG segment. Also to determine whether consumers in Kolkata are risk takers when it comes to buying extended FMCG products.

(iii) Identify the factors that influence the consumers to accept brand extensions in FMCG products. 


\section{Research Methodology}

The Research Methodology that has been adopted to carry out this research study includes both exploratory and empirical work. The exploratory study is based on the findings out of books on this issue written by various authors, articles published in journals, magazines, periodicals, newspapers, and web materials. The study has also taken figures and facts from Government sources and Annual Reports of the FMCG companies. Theoretical Framework has been developed for the research study. The empirical part is based on the questionnaires prepared and distributed among consumers.

\subsection{Questionnaire Development}

The questionnaire has been developed in such a way so as to serve the purpose and objectives of the study. The questionnaire for the consumers has been divided into two sections- Demographical Data and Technical Data (i.e. subject related data). As Brand and Brand Extension aspects are related with consumers' perceptions, emotions and associations, the Demographical Factors are important for this study. The Technical questions in the Kolkata Consumers survey questionnaire are mostly structured, with multiple-choice questions, some of which have been framed by using Likert 5-point scale where ever required.

\subsection{Reliability and Internal Consistency of Questionnaire}

The consumer survey questionnaire has been evaluated through testing of reliability and internal consistency, using SPSS. Cronbach's Alpha is used as a measure of internal consistency, i.e. do all the items within the instrument measure the same thing. The closer the Alpha value is towards 1.00, the greater the internal consistency of items in the instruments being assessed. The formula for determining Alpha makes use of the number of items in the scale $(\mathrm{k})$ and the average correlation between pairs of items. The Cronbach's Alpha for the questionnaire worked out to 0.832 , which is very close to 1 . Hence, the questionnaire is reliable and internally consistent.

The questionnaire from the consumer's point of view consisted of 30 questions, out of which 13 questions are related to Biographical or Demographical aspects. The balance 17 questions are technical questions, using the Likert 5 point scale and dichotomous scales. The questions are framed in such a manner so as to address the research objectives.

\subsection{Sample Selection, Survey and Data Collection}

\subsubsection{Determination of Sample size}

Since the survey on brand extension in FMCG segment has been carried out in Kolkata, the geographical boundary has been considered as per the Kolkata city limits as defined by the Wards under the Kolkata Municipal Corporation (KMC). The area under KMC consists of 141 Wards, grouped under 15 Boroughs.

As per the Census Data Report, 2011 [26] brought out by the Government of India, Ministry of Home Affairs, Kolkata's population in 2011 stands at 4,496,694 numbers, the male and female population being $2,356,766$ and 2,139,928 numbers respectively. To make the sample as representative as possible, the survey had been carried out so as to include respondents from all the 141 Wards. Initially, information was collected from KMC and some Borough offices to identify the Wards and the locality / area under each Ward. The Questionnaires were administered among the respondents of the wards. 15 questionnaires for each Ward was distributed, and the number of valid responses varied between 6 (minimum) to 13 (maximum) per Ward which has been used for the purpose of this study. The eastern part of Kolkata covers the smallest number of Wards. In the survey, the random sampling method has been adopted. The final usable sample size for the research work analysis comprised of 1041 valid respondents covering all 141 wards in Kolkata.

In this research study, the sample size taken is 1041 which is much higher than the required sample size of 384 at 95\% Confidence Level, with at 5\% Margin of Error and 50\% Response Distribution. Even at 99\% Confidence Level with $5 \%$ Margin of error, the sample size would have been 663, which is well within the research sample size of 1041. This larger sample size of 1041 has resulted as all 141 wards have been covered, to make the sample as representative as possible. As stimuli the present study has considered 11 well known brands those who have extended to various products.

\section{Data Analysis And Interpretations Of Research Findings}

The demography and technical analysis of the survey has given the necessary inputs to understand the Kolkata consumers' perception and evaluation of brand extension strategies in the FMCG segment. The primary objective of the research is to examine in-depth the perceptions and purchase behavior pattern of Kolkata consumers with respect to product launches through brand extensions in the FMCG segment. The exploratory research provided valuable insight into the attitude of consumers towards brand extension. Based on the literature study, the following hypotheses have been established, 
$\mathbf{H}_{1}$ : Similarity and fit between the parent brand and extended brand are important for consumers' evaluation of brand extension in FMCG segment.

$\mathbf{H}_{2}$ : Reputation of the parent brand influences the consumers to buy extended brand of FMCG product.

$\mathbf{H}_{3 \text { : }}$ Kolkata consumers are low risk takers.

In the present study, crosstabulation analysis has mainly been considered, as the variables are categorical in nature. A crosstabulation is a joint frequency distribution of cases based on two or more categorical variables. Displaying a distribution of cases by their values on two or more variables is known as contingency table analysis and is one of the most commonly used analytical methods in the social sciences. The joint frequency can be analysed with the Chi-square statistics $\left(\chi^{2}\right)$ to determine whether the variables are statistically independent or whether they are associated. If a dependency between variables exists, then other indicators such as Cramer's V, Phi, Gamma and so forth can be used to describe the degree which the values of one variable associate or vary with those of other variable.

\subsection{Hypothesis Testing : $\mathrm{H}_{1}$}

Cross tabulation analysis between the variables have been made to find out the joint frequency. The joint frequencies have been analyzed through Chi-Square statistics $\left(\chi^{2}\right)$ to determine whether the variables are statistically independent or whether the variables are associated. Table 3, gives a summary of the analysis.

Table 3 Summary of Analysis of Frequency Tables, Cross-Tabulations \& Chi-Square Test for Independence of Attributes. Cramer's V to measure Degree of Association.

\begin{tabular}{|c|c|c|c|c|}
\hline Cross Tabulation & Chi-Square Value & df & p-Value & Cramer' V \\
\hline $\begin{array}{l}\text { 1. Do you think similarity between Parent Brand \& Extended } \\
\text { brand is important? * Do you always buy branded products? }\end{array}$ & 364.99 & 3 & $<0.001$ & 0.592 \\
\hline $\begin{array}{l}\text { 3. Do you think similarity between Parent Brand \& Extended } \\
\text { brand is important? * Do you purchase follow up (extended) } \\
\text { brands? }\end{array}$ & 288.18 & 1 & $<0.001$ & 0.526 \\
\hline $\begin{array}{l}\text { 4. Do you think similarity between Parent Brand \& Extended } \\
\text { Brand is important? * family Income }\end{array}$ & 19.77 & 4 & $<0.001$ & 0.138 \\
\hline $\begin{array}{l}\text { 5. Do you think similarity between Parent Brand \& Extended } \\
\text { Brand is important? * Gender }\end{array}$ & 31.22 & 1 & $<0.001$ & 0.173 \\
\hline $\begin{array}{l}\text { 6. Do you think similarity between Parent Brand \& Extended } \\
\text { Brand is important? } * \text { Age }\end{array}$ & 34.57 & 7 & $<0.001$ & 0.182 \\
\hline
\end{tabular}

Interpretation of findings: from Table 3 it has been found that a significantly large proportion of the respondents from Kolkata who are brand loyal consumers, and buy branded products regularly and buy follow up brands of the parent brands, feel similarity and fit between parent brands and their extended brands are very important. There is a strong association between the variables, 1, 2, 3, mentioned in the Table 3 above, Cramer's $\mathrm{V}$ being calculated as $0.592,0.519$ and 0.526 respectively. The calculated value of Pearson's Chi-Square values for 1, 2 and 3 are $364.99,280.62,288.18$ with p-value $<0.001$ show that the result is significant and the variables are not independent of each other. This is true irrespective of age, income, gender and profession as in all cases the p-values are $<0.001$. However, profession/occupation has close association with the similarity between parent and extended brand. Age, income and gender have a moderate relationship with the similarity factor. Table 4 shows how consumers of Kolkata think the above extended FMCG products are similar to their parent brands. In most of the cases they feel the existence of similarities between the parent and extended branded products are important with p-value calculated $<0.001$.

Table 4 Similarity between 11 FMCG parent brands and their extended brand using Pearson's Chi-Square test

\begin{tabular}{|l|c|c|c|}
\hline \multicolumn{1}{|c|}{ Parent Brand vs Extended Brand } & \multirow{2}{*}{ df } & \multicolumn{2}{l|}{ Pearson's Chi-Square } \\
\cline { 3 - 4 } & & Value & $\begin{array}{c}\text { Asymp. Sig } \\
\text { (p-value) }\end{array}$ \\
\hline Maggie Noodle vs. Maggie Sauce & 3 & 246.504 & $<0.001$ \\
\hline Lifebuoy Soap vs. Lifebuoy Hand Wash & 5 & 51.845 & $<0.001$ \\
\hline Dettol Antiseptic vs. Dettol Soap & 4 & 147.061 & $<0.001$ \\
\hline Pond's Cream vs. Pond's Powder & 4 & 286.565 & $<0.001$ \\
\hline Knorr Soup vs. Knorr Soupy Noodles & 4 & 403.089 & $<0.001$ \\
\hline Dove Soap vs. Dove Shampoo & 4 & 156.069 & $<0.001$ \\
\hline Lux Soap vs. Lux Body Gel & 4 & 116.542 & $<0.001$ \\
\hline Vivel Soap vs. Vivel Ultrapro Shampoo & 4 & 201.271 & $<0.001$ \\
\hline Keo-Karpin Hair Oil vs. Keo-Karpin Hair Vitalizer & 4 & 212.244 & $<0.001$ \\
\hline Amul Milk vs. Amul Butter & 4 & 242.581 & $<0.001$ \\
\hline Boroline Cream vs. Boroline Suthal & 4 & 116.950 & $<0.001$ \\
\hline
\end{tabular}


Therefore, Image similarity between Parent Brand and Extended Brand is very important and proved to be significant (First Hypothesis).

\subsection{Hypothesis Testing : $\mathbf{H}_{2}$}

A Summary of the analysis of Cross-Tabulations \& Chi-Square Test for Independence of Attributes and Cramer's V to measure Degree of Association is given in Table 5. It has been found that in all the 1, 2, 3, 4, 5 cases stated below, reputation influences the brand loyal consumers of Kolkata to buy parent brand's extended product. The consumers belonging to Kolkata who think similarity and fit between parent and extended brands are important, also buy extended products because of parent brand's reputation. Reputation of parent brand matters for safety and security and to buy follow up brand. All the variables are not independent of each other, p-value showing $<0.001$. The variables are closely associated with each other as it has been observed in the value determined in Cramer's V.

Table 5

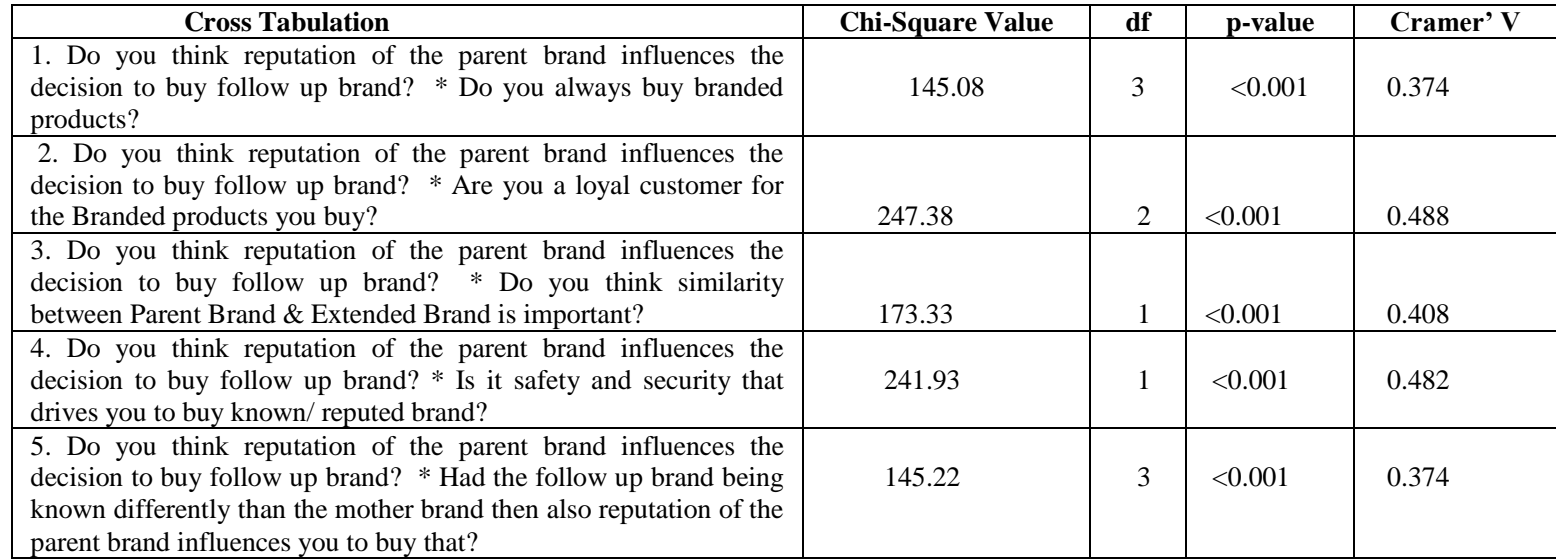

When the 11 FMCG parent brands and their extended brands are cross tabulated with the variable 'Reputation' of the parent brand influence the consumers to buy follow up brand, the following results emerged (Table 6)

Table 6

\begin{tabular}{|l|c|c|c|}
\hline \multirow{2}{*}{ Parent Brand and Extended Brand } & \multirow{2}{*}{ df } & \multicolumn{2}{|c|}{ Pearson's Chi-Square } \\
\cline { 3 - 4 } & Value & 0.004 \\
\hline Maggie Noodle vs. Maggie Sauce & 4 & 15.664 & 0.001 \\
\hline Lifebuoy Soap vs. Lifebuoy Hand Wash & 5 & 288.750 & 0.006 \\
\hline Dettol Antiseptic vs. Dettol Soap & 4 & 14.322 & 0.095 \\
\hline Pond's Cream vs. Pond's Powder & 4 & 7.974 & 0.001 \\
\hline Knorr Soup vs. Knorr Soupy Noodles & 4 & 296.827 & 0.002 \\
\hline Dove Soap vs. Dove Shampoo & 4 & 16.568 & 0.001 \\
\hline Lux Soap vs. Lux Body Gel & 4 & 265.794 & 0.001 \\
\hline Vivel Soap vs. Vivel Ultrapro Shampoo & 4 & 186.618 & 0.001 \\
\hline Keo-Karpin Hair Oil vs. Keo-Karpin Hair Vitalizer & 4 & 40.832 & 0.001 \\
\hline Amul Milk vs. Amul Butter & 4 & 156.429 & 0.005 \\
\hline Boroline Cream vs. Boroline Suthal & 4 & 14.759 & \\
\hline
\end{tabular}

Interpretation: reputation of the parent brand has influenced the respondents to buy follow up brand. Ten of the FMCG products except Pond's as shown in Table 6 above show that reputation of the parent brands induce them to buy their extended products, p-value $<0.05$ (except Pond's, p-value $<0.095$ ). This indicates that the reputation of the FMCG parent brands influence the consumers to buy their extended products. Therefore, it can be concluded that "Reputation of the Parent Brand" influences the consumers to buy extended product (Second Hypothesis). 


\subsection{Hypothesis Testing: $\mathrm{H}_{3}$}

Table 7

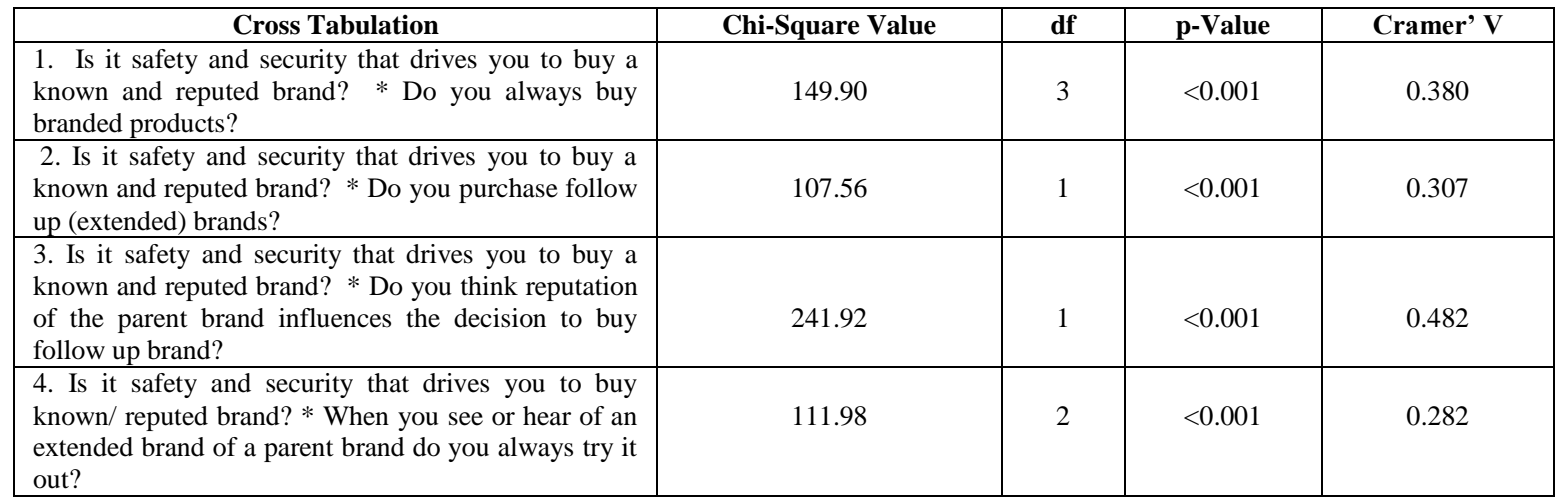

Interpretation: from Table 7, it has been observed that the majority of the respondents buy well known and reputed brands because of safety and security. They do not experiment with the new products. They try out follow up brands of the reputed parent brands for safety and security. The p-value in all the cases in the above Table came to $<0.001$ indicating the variables are not independent of each other. The Cramer's V values also indicating there is close relationship between choosing a known brand in order to avoid perceived risks. Therefore, Kolkata consumers are low risk takers as they stick to known brands in order to avoid uncertainty in new brands, thereby accepting the Third Hypothesis.

\section{Conclusions}

The consumers of Kolkata are very much brands loyal and they stick to the brands which they like and enjoy most. The retail offers and displays occasionally induce them to shift to new brands but normally they do not experiment much with the new brands. But consumers of Kolkata normally do not experiment much. Therefore, Kolkata consumers are low risk takers. This phenomenon exists irrespective of age, income group and gender. However, they try out extended FMCG product of the parent brand. The reputation of the parent brand also gives a positive impact on the consumers mind. The stronger the parent brand, easier for it to extend. Image similarity and category fit between the parent brand and extended brand is very important. They feel similarity between parent and extended brands help them to associate with the new products. As it has been observed Pond's Cream (parent brand) has less similarity with Pond's Powder and not accepted by the respondents.

\section{Limitations}

a) The study is confined to Kolkata only. Hence, perceptions of the consumers are restricted to Kolkata's consumer only. Hence, the result may vary in other parts of the country.

b) In the survey only 11 FMCG products have been considered. There are many FMCG products available in the market.

c) The study covered 141 wards. But the people who come to Kolkata for jobs or other purpose but stay outside Kolkata have been ignored.

\section{References}

[1] Gamble, T. (1967): "Brand Extension, in Plotting Marketing Strategy", Interpublic Press Books, New York.

[2] Chung, K.M., Anna, M.L., and Margo, S. (2001): "Consumer evaluations of vertical brand extensions and core brands". Journal of Business Research, vol. 52(3), pp 211-222.

[3] Tauber, E. (1988): "Brand Leverage: Strategy for growth in a cost control world". Journal of Advertising Research, Vol.28(4), pp 26-30.

[4] Aaker, David, A., (1991): "Managing Brand Equity: "Capitalizing on the value of a Brand Name"; The Free Press; New York.

[5] Kapferer J.N. (2004): "The New Strategic Brand Management; Creating and Sustaining Brand Equity Long Term"; Kogan Page Limited.

[6] Kim, Chung, K. and Lavack, Anne, M. (1996): "Vertical Extensions: Current Research and Managerial Implications", Journal of Product and Brand Management, Vol.56, pp 24-37.

[7] Nijssen, E.J. (1999): "Success Factors of Line Extensions of FMCG"; European Journal of Marketing, 33 (516),pp 450-469

[8] Chernatony, L. de., Hem, L.E., and Iverson, N.M. (2003): "Factors influencing successful brand extensions". Journal of Marketing Management, vol.19, pp 781-806.

[9] Grime I., Diamantopoulos A., and Smith G. (2002): "Consumer Evaluations of Extensions and Their Effects on Core Brand"; European Journal of Marketing, 36 (11/12), pp 1415-1438.

[10] Kotler, P.G., Amstrong, H.A., Swee, M.L (2006); "Principles of Marketing- An Asian Perspective", $11^{\text {th }}$ Edition, Prentice Hall.

[11] Swaminathan, Vanitha, Fox, Richard J., Reddy, Srinivas K., (2001): "The Impact of Brand Extension Introduction on Choice", Journal of Marketing, Vol. 65 Issue 4, p1-15.

[12] IBEF Report, 2013. 
[13] Nielsen's Survey Report, 2012

[14] The Economic Times of India, Top 500 Companies, 2013.

[15] Tauber, E.M. (1981): "Brand Franchise Extension; New Product Benefits From Existing Brand Names; Business Horizon, Vol.24, pp-36-41.

[16] Aaker, David, A, and Keller, K.L., (1990): “Consumer Evaluation of Brand Extensions”; Journal of Marketing; vol. 54 (January); pp 27-41.

[17] Park, C.W., Milberg, S. and Lawson, R. (1991): "Evaluation of Brand Extensions, the Role of Product Similarity and Brand Concept Consistency"; Journal of Consumer Research, (September), pp-193.

[18] Boush, D.M. and Loken, B. (1991): "A Process- Tracing Study of Brand Extension Evaluation”, Journal of Marketing Research, Vol. 28, pp-16-28.

[19] Thamaraiselvan, N. and Raja, J. (2008),: "How do Consumers Evaluate Brand Extensions -Research Findings from India", Journal of Services Research, Vol. 8 Issue 1, pp 43-62.

[20] Loken, B and John, R.D. (1993): "Diluting Brand Beliefs; Where Do Brand Extensions Have A Negative Impact?" Journal of Marketing, 57 (July), pp 71-84.

[21] Franziska Völckner \& Henrik Sattler (2006): "Drivers of Brand Extension Success", Journal of Marketing, Vol. 70, pp 18-34.

[22] Apostolopoulou, A. (2002): "Brand Extensions by U.S. Professional Sport Teas, Motivations and Keys to Success"; Sports Marketing Quarterly, Vol. 11, No.4.

[23] Pitta, A and Katsanis P.L. (1995) : "Understanding Brand Equity for Successful Brand Extension"; Journal of Consumer Marketing 12 (4) pp 51-64.

[24] Chen, C.H. Chen. (2000): "Brand Dilution Effect of Extension Failure- A Taiwan Study"; Journal of Product and Brand Management, vol. 9(4), pp-243-254.

[25] Ries A.L. and Trout T. (1986): "Positioning The Battle For Your Mind" (1 ${ }^{\text {st }}$ Ed), New York, McGraw Hill.

[26] The Census Report, Government of India, 2011. 